\title{
Determining the Cytotoxicity of Rare Earth Element Nanoparticles in Macrophages and the Involvement of Membrane Damage
}

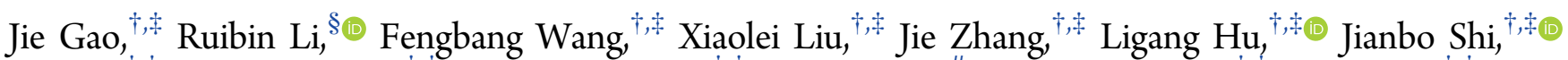

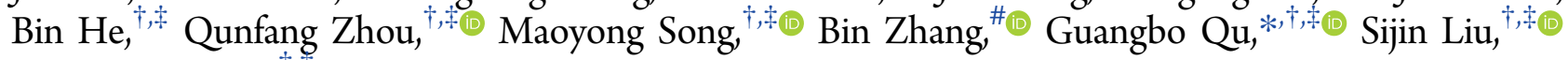 \\ and Guibin Jiang
}
${ }^{\dagger}$ State Key Laboratory of Environmental Chemistry and Ecotoxicology, Research Center for Eco-Environmental Sciences, Chinese Academy of Sciences, Beijing 100085, People's Republic of China
${ }^{\S}$ School for Radiological and Interdisciplinary Sciences (RAD-X), Collaborative Innovation Center of Radiation Medicine of Jiangsu Higher Education Institutions, Jiangsu Provincial Key Laboratory of Radiation Medicine and Protection, Soochow University, Suzhou, Jiangsu 215123, People's Republic of China
${ }^{\#}$ School of Chemistry and Chemical Engineering, Shandong University, Jinan 250100, People's Republic of China
${ }^{\ddagger}$ University of Chinese Academy of Sciences, Beijing 100049, People’s Republic of China

\section{Supporting Information}

\begin{abstract}
Rare earthelement nanomaterials (REE NPs) hold considerable promise, with high availability and potential applications as superconductors, imaging agents, glass additives, fertilizers additives and feed additives. These results in potential REE NP exposure to humans and the environment through different routes and adverse effects induced by biological application of these materials are becoming an increasing concern. This study investigates the cytotoxicity of REE NPs: $\mathrm{nLa}_{2} \mathrm{O}_{3}, \mathrm{nEu}_{2} \mathrm{O}_{3}, \mathrm{nDy}_{2} \mathrm{O}_{3}$ and $\mathrm{nYb}_{2} \mathrm{O}_{3}$ from 2.5 to $80 \mu \mathrm{g} / \mathrm{mL}$, in macrophages. A significant difference was observed in the extent of cytotoxicity induced in macrophages by differential REE NPs. The highatomic number materials (i.e., $\mathrm{nYb}_{2} \mathrm{O}_{3}$ ) tending to be no toxic whereas low-atomic number materials $\left(\mathrm{nLa}_{2} \mathrm{O}_{3}\right.$ and $\mathrm{nEu}_{2} \mathrm{O}_{3}$ and $\left.\mathrm{nDy}_{2} \mathrm{O}_{3}\right)$ induced $75.1 \%, 53.6 \%$ and $20.7 \%$ dead cells. With $\mathrm{nLa}_{2} \mathrm{O}_{3}$ as the representative material, we demonstrated that $\mathrm{nLa}_{2} \mathrm{O}_{3}$ induced cellular membrane permeabilization, through the sequestration of phosphates from membrane. The further mechanistic investigation established that membrane damage induced intracellular calcium increased to 3.0- to 7.3-fold compared to control cells. This caused the sustained overload of mitochondrial calcium by approximately 2.4 -fold, which regulated cell necrosis. In addition, the injury of cellular membrane led to the release of cathepsins into cytosol which also contributed to cell death. This detailed investigation of signaling pathways driving REE NP-induced toxicity to macrophages is essential for better understanding of their potential health risks to humans and the environment.
\end{abstract}

\section{INTRODUCTION}

Owing to their unique physical-chemical properties, rare earth elements (REEs) have been extensively applied as superconductors, imaging agents, glass additives, fertilizers additives and feed additives, etc. ${ }^{1-3}$ For instance, addition of $\mathrm{Eu}_{2} \mathrm{O}_{3}$ to $\mathrm{ZnO}$ films could improve the optical and structural properties and intense luminescence. ${ }^{4} \mathrm{Yb}_{2} \mathrm{O}_{3}$ has been reported as a novel long circulation material as an in vivo $\mathrm{CT}$ imaging agent. ${ }^{5}$ $\mathrm{Yb}_{2} \mathrm{O}_{3}$ could be applied for novel additive material for concentrator solar cells, as a the solar energy converter. ${ }^{6}$ $\mathrm{Dy}_{2} \mathrm{O}_{3}$ nanoparticles mixed gadolinium-dysprosium oxide nanoparticles showed promising characteristics as a MRI contrast agent for imaging. ${ }^{7}$ It has been reported that fertilizers contain approximate $30 \%$ of $\mathrm{La}_{2} \mathrm{O}_{3}$. Commercial feed additives for poultry containing 50\% REEs and $\mathrm{La}_{2} \mathrm{O}_{3}$ accounts for $20 \%$ of REE oxides. 8

With the increase in application of REEs worldwide, thousands of tons of REEs enriched fertilizers released into the agricultural soil, resulting in the large scale of contamination of REEs in soil and water near the mining sites REEs. ${ }^{3,10-14}$ For instance, because of the large REE reserves, China is the largest worldwide producer and supplier of REEs. ${ }^{9}$ It has been evaluated in 2002 that REE containing fertilizers discharged into the cultivated soil are above 5000 tons in China. ${ }^{3}$ Therefore, application of REEs has enhanced the large scale contamination of REEs, displaying high accumulative in contaminated environmental compartments, and been considered persistence in environment and bioaccumulation in biota. ${ }^{15}$ REEs containing food products, industrial products or medicinal agents could be intake through oral, intravenous injection and skin exposure. ${ }^{16}$ The exposed REEs could

Received: August 18, 2017

Revised: October 10, 2017

Accepted: November 9, 2017

Published: November 9, 2017 
accumulate in blood, brain and bone after introducing to human body, ${ }^{17}$ leading to a great concern for human health. ${ }^{18-21}$ The inhalation of air-borne particles of REEs oxides is the most typical accidental exposure route. ${ }^{22}$ Because of the chronic ingestion of REEs, the population living in highREE-background showed abnormality in activities of some digestive enzymes. ${ }^{23}$ As various nanomaterials containing REEs have been developed as probes for imaging, ${ }^{24-28}$ these direct administrations of these REEs containing nanomaterials, therefore, may also result in a potential risk to human health. It has been reported fibrosis and renal disorders in patients when Gd elements (9-25 $\mathrm{mmol})$ used as an imaging agent. $^{18,29-31}$ At the nanoscale, REE nanoparticles (REE NPs) present remarkably different biological activities in comparison to their larger-scale counterparts, with the higher surface area significantly altering cellular uptake and biodistribution in vivo, resulting in altered biological effects. ${ }^{31}$ Therefore, improved understanding of the impacts on biological systems induced by these materials is highly beneficial for the prevention of side effects in biomedical applications. ${ }^{32}$

Macrophages are considered a vital sentinel cell, forming a defensive line to combat invading pathogens and they also take a prominent role in the clearance of nanomaterials from circulatory systems and local organs. ${ }^{26}$ Because of the instinct role of macrophage, the high accumulation level of environmental particles in these cells and the resulted negative effects are considered the dominant risk upon particle exposure. Disordered macrophages not only lose their defense activity, but also have been found to trigger various pathologies such as autoimmune diseases, ${ }^{33}$ inflammation and pneumonitis. ${ }^{34}$ For instance, atmospheric particles could be cleared by macrophages located in lung and the accumulation of particle in macrophages leads to sustainable inflammation, and the resulted in lung diseases. ${ }^{35,36}$ The environmental exposure of atmospheric particle has been demonstrated to trigger lung cancer due to the inflammation initiated by lung macrophages. $^{35,36}$ Exposure to REE NPs has been associated with nephrogenic systemic fibrosis in patients, ${ }^{18}$ because macrophage internalized REE NPs such as $\mathrm{La}_{2} \mathrm{O}_{3}$ and $\mathrm{Eu}_{2} \mathrm{O}_{3}$ cause the transfer of phosphates from lipids, leading to membrane damage and injury to lysosomal cell membranes, promoting activation of the multiprotein oligomer NLRP3 inflammasome. ${ }^{37-43}$ However, as a lack of complete understanding of the mechanisms underlying REE NP effect on macrophages, the impact of REE NPs on cell survival and viability is at present still unclear. Therefore, the investigation on the toxicity of REE NPs with macrophage as cell model is of help to evaluate their risks under the exposure REE NPs by various routes.

Physicochemical properties such as elemental composition, shape, size and surface groups largely dictate the toxicity profiles of nanomaterials. ${ }^{26}$ Therefore, different REE NPs are therefore assumed to induce distinct biological effects. In the present study, we investigated the cytotoxicity of REE NPs on the survival of macrophages, establishing potential mechanisms responsible for the cytotoxicity induced by these materials. These findings show a safer pathway for the design of REEcontaining nanomaterials, for application in biomedical systems.

\section{MATERIALS AND METHODS}

Chemicals and Reagents. Dulbecco's Modified Eagle's Medium (DMEM), penicillin/streptomycin and L-glutamine were all purchased from Invitrogen (Carlsbad, USA). Fetal bovine serum (FBS) was obtained from Atlanta Biologicals Inc. (Lawrenceville, USA). All horseradish peroxidase-conjugated secondary antibodies were obtained from GE Healthcare Life Sciences (Pittsburgh, USA). The mammalian protein extraction reagent and ECL reagent were purchased from Thermo Fisher Scientific (Waltham, USA). The protein inhibitor cocktail, $2^{\prime}, 7^{\prime}$-dichlorodihydrofluorescein diacetate (DCFH-DA), rapamycin and tetramethylrhodamine methyl ester (TMRM) were purchased from Sigma-Aldrich (Shanghai, China). The Bradford reagents for protein determination were obtained from Bio-Rad (Shanghai, China). The following antibodies (Abs) were used: anti-Bid $\mathrm{Ab}$ from $\mathrm{R} \& \mathrm{D}$ Systems (Minneapolis, USA), anti-LC-3 Ab from Novagen (Medison, USA), whereas anti-GAPDH and anti-Caspase $3 \mathrm{Ab}$ were purchased from Cell Signaling Technology (Shanghai, China). 4-(6Acetoxymethoxy-2,7-dichloro-3-oxo-9-xanthenyl)-4'-methyl$2,2^{\prime}$ (ethylenedioxy)dianiline- $N, N, N^{\prime}, N^{\prime}$-tetraacetic acid tetrakis (acetoxymethyl) ester (Fluo-3/AM), 9-[4-[bis[2-[(acetyloxy)methoxy]-2-oxoethyl]amino]-3-[2-[2-[bis[2-[(acetyloxy)methoxy]-2-oxoethyl] amino]-5-methylphenoxy] ethoxy]phenyl]-3,6-bis(dimethylamino)xanthylium bromide(Rhod-2), E-64d, Pepstatin A, CA-074 methyl ester (CA-074Me), Cyclosporin A (CsA), Cytochalasin D, ethylenediaminetetraacetic acid (EDTA) and Z-VAD-fmk were purchased from MedChem Express (Monmouth Junction, USA).

Nanomaterials and Characterization. All REE NPs including $\mathrm{La}_{2} \mathrm{O}_{3} \mathrm{NP}\left(\mathrm{nLa}_{2} \mathrm{O}_{3}\right), \mathrm{nEu}_{2} \mathrm{O}_{3}, \mathrm{nDy}_{2} \mathrm{O}_{3}$ and $\mathrm{nYb}_{2} \mathrm{O}_{3}$ (sources of REE NPs are shown in Table $\mathrm{S} 1$ ) were prepared in endotoxin-free water forming stock solutions of $5 \mathrm{mg} / \mathrm{mL}$. Before characterization or exposure, REE NPs were sonicated at $32 \mathrm{~W}$ for $30 \mathrm{~s}$. High-resolution transmission electron microscopy (HRTEM) samples were prepared by depositing of REE NP suspension $(20 \mu \mathrm{g} / \mathrm{mL})$ onto a carbon-coated copper electron microscopy grid (Beijing Zhongingkeyi Technology Co., Ltd., China) and dried under ambient conditions overnight before analysis using a HRTEM (JEOL-2100F, Japan). The $\zeta$ potential and hydrodynamic diameters of REE NPs in DMEM medium were determined using a Zetasizer (Malvern Nano series, Malvern, U.K.). Fourier transform infrared spectroscopy (FT-IR) was performed using a Nicolet 6700 FT-IR spectrophotometer (Thermo Fisher Scientific Inc., USA), according to the $\mathrm{KBr}$ pellet method. X-ray photoelectron spectroscopy (XPS) determination of REE NPs was performed using sample deposits on silicon wafers, where samples were air-dried prior to analysis.

Cell Culture, Cellular Treatment and Toxicity Assays. J774A.1 cells and Hep1-6 cells were purchased from the Shanghai Cell Bank of Type Culture Collection of China. Following treatment at 2.5, 10, 20, 40 and $80 \mu \mathrm{g} / \mathrm{mL}$, cells were stained using $50 \mu \mathrm{g} / \mathrm{mL}$ propidium iodide (PI) in phosphatebuffered saline (PBS), with dead cells analyzed by flow cytometric analysis. ${ }^{38,44-46}$ The CellTox Green Cytotoxicity assay was used to determine cytotoxicity according to manufacturer instructions (Promega, Shanghai, China).

J774A. 1 cells were preincubated with $1 \mu \mathrm{M}$ cytochalasin $\mathrm{D}$, $50 \mu \mathrm{M}$ EDTA or $2 \mathrm{nM}$ rapamycin for $2 \mathrm{~h}$, respectively, followed by exposure to $20 \mu \mathrm{g} / \mathrm{mL} \mathrm{nLa}_{2} \mathrm{O}_{3}$ with or without cytochalasin D, EDTA or rapamycin. Cell death was then evaluated using PI staining after $24 \mathrm{~h}$.

RAW-Difluo mLC3 cells (invivogen) were cultured in DMEM containing $10 \%(\mathrm{v} / \mathrm{v}) \mathrm{FBS}, 50 \mathrm{U} / \mathrm{mL}$ penicillin, 50 $\mathrm{mg} / \mathrm{mL}$ streptomycin, $100 \mathrm{mg} / \mathrm{mL}$ Normocin and $2 \mathrm{mM} \mathrm{L}-$ glutamine. Before the exposure experiment, the culture medium 
was changed with DMEM containing heat-inactivated FBS (30 min at $56{ }^{\circ} \mathrm{C}$ ), $50 \mathrm{U} / \mathrm{mL}$ penicillin, $50 \mathrm{mg} / \mathrm{mL}$ streptomycin, 2 $\mathrm{mM}$ L-glutamine and $4.5 \mathrm{~g} / \mathrm{L}$ glucose, $10 \%(\mathrm{v} / \mathrm{v})$. After $24 \mathrm{~h}$, RAW-Difluo mLC3 cells was treated with $\mathrm{nLa}_{2} \mathrm{O}_{3}$ for $6 \mathrm{~h}$ followed by the observation with confocal microscopy.

Inductively Coupled Plasma-Mass Spectrometry (ICPMS) Analysis for Cellular Uptake of Nanomaterials. Cells were cultured in $10 \mathrm{~cm}$ plates and treated with $20 \mu \mathrm{g} / \mathrm{mL}$ REE NPs for $6 \mathrm{~h}$. Cells were washed 3 times with PBS. Then we collected and digested the cells by combining with RIPA buffer containing $1 \%$ protease cocktail (Sigma-Aldrich) on ice for 30 min. After centrifugation at $15,000 \mathrm{~g}$ for $30 \mathrm{~min}$ at $4{ }^{\circ} \mathrm{C}$, the protein concentrations of the supernatant of cellular lysates were determined using the Bradford method. The suspension of cell lysates post centrifugation ICP-MS or the pellets of cellular lysates were digested for ICP-MS determination. In brief, $200 \mu \mathrm{L}$ of supernatants or pellets was digested with 200 $\mu \mathrm{L}$ of nitric acid- $\mathrm{H}_{2} \mathrm{O}_{2}(3: 1)$ at $75^{\circ} \mathrm{C}$ for $12 \mathrm{~h}$, respectively. The digested solutions were diluted to $10 \mathrm{~mL}$ with the acid concentration below $3 \%(\mathrm{v} / \mathrm{v})$ and subjected to ICP-MS analysis to determine the quantity of particulate REEs ( $\mathrm{La}, \mathrm{Eu}$, $\mathrm{Dy}$ and $\mathrm{Yb}$ ). All analyses were performed in triplicates using the external calibration method. The standard mixture solution for REE determination was purchased from Guobiao (Beijing) Testing \& Certification Co., Lta. (Beijing, China). The calibration curve is shown in Figure S1 (Supporting Information). Linear regressions showed that $R$ was above 0.99 (Figure S1). The signal intensity repeatability (RSD) of standard was $9.4 \%$. Each group includes at least 3 parallel samples, and the average value was calculated. The sum of the dissolved REE and particulate REE content is defined as the total intracellular REE concentration. The intracellular total REEs concentration was expressed as REE content (ng) versus intracellular protein level ( $\mathrm{mg}$ ).

Transformation of REE NPs in Phagolysosomal Simulant Fluid (PSF). Nanoparticles were dissolved in $1 \mathrm{~mL}$ of PSF solution $\left(142 \mathrm{mg} / \mathrm{L} \mathrm{Na}_{2} \mathrm{HPO}_{4}, 6.65 \mathrm{~g} / \mathrm{L} \mathrm{NaCl}, 62 \mathrm{mg} /\right.$ $\mathrm{L} \mathrm{Na}_{2} \mathrm{SO}_{4}, 29 \mathrm{mg} / \mathrm{L} \mathrm{CaCl} \cdot \mathrm{H}_{2} \mathrm{O}, 250 \mathrm{mg} / \mathrm{L}$ glycine, $8.09 \mathrm{~g} / \mathrm{L}$ potassium phthalate, $\mathrm{pH} 4.5$ ) at a concentration of $50 \mu \mathrm{g} / \mathrm{mL}$ and sonicated at $32 \mathrm{~W}$ for $30 \mathrm{~s}$. Samples were incubated at 37 ${ }^{\circ} \mathrm{C}$ for either $0.25,0.5,1,3$ or $6 \mathrm{~h}$, prior to centrifugation at $15,000 \mathrm{~g}$ for $30 \mathrm{~min}$. Pellets were analyzed by inductively coupled plasma-optical emission spectrometry (ICP-OES) to assess the concentrations of phosphorus and REE ions, whereas suspensions were digested and REE ion concentrations were determined by ICP-MS. ${ }^{38}$

Assessment of Lysosomal Membrane Permeabilization (LMP). Regarding concentration selection, for the investigation of the cytotoxicity of $\mathrm{nLa}_{2} \mathrm{O}_{3}$ as the representative material, $20 \mu \mathrm{g} / \mathrm{mL}$ was frequently selected because the concentration higher than $20 \mu \mathrm{g} / \mathrm{mL}(40$ or $80 \mu \mathrm{g} / \mathrm{mL})$ possess dramatic toxicity and could induced cell detached from the tissue culture dish. As a result, some experiments such as confocal fluorescence observation could not performed under the exposure concentration higher than $20 \mu \mathrm{g} / \mathrm{mL}$. After exposure to $20 \mu \mathrm{g} / \mathrm{mL} \mathrm{nLa} \mathrm{O}_{3}$ in DMEM for $6 \mathrm{~h}$, J774A.1 cells were washed with PBS and then stained with Magic Red Cathepsin B (ImmunoChemistry Technologies, Bloomington, USA) for $2 \mathrm{~h}$ according to manufacturers' instructions. The plasma membrane was stained using a membrane labeling kit (Sigma-Aldrich, Shanghai, China) and nuclei were stained with Hoechst 33342 (Thermo Fisher Scientific, Waltham, USA), at room temperature for $1 \mathrm{~h}$. Finally, cells were visualized using a
TCS SP5 laser scanning confocal microscope (Leica, Germany).

Calcium Flux Analysis and Mitochondrial Potential Assessment. Alterations to concentrations of intracellular $\mathrm{Ca}^{2+}$ and mitochondrial $\mathrm{Ca}^{2+}$ were monitored using Fluo-3/AM and Rhod-2 fluorescence probes, respectively. Briefly, after treatment $\mathrm{nLa}_{2} \mathrm{O}_{3}$ at $20 \mu \mathrm{g} / \mathrm{mL} 1 \times 10^{5}$ cells were incubated at $37^{\circ} \mathrm{C}$ in the dark with $4 \mu \mathrm{M}$ Fluo-3/AM and $4 \mu \mathrm{M}$ Rhod- 2 for $20 \mathrm{~min}$. Cells were then washed 3 times and resuspended in Hank's Balanced Salt Solution without $\mathrm{Ca}^{2+}$ and $\mathrm{Mg}^{2+}$. Cells treated with REE NPs were additionally stained with $20 \mathrm{nM}$ TMRM, then analyzed by flow cytometry (FACS) for mitochondrial membrane assessment. FACS analysis was performed using an LSR II flow cytometer (Becton Dickinson, Mountain View, USA) equipped with a single $488 \mathrm{~nm}$ argon laser. Fluo-3/AM fluorescence was assessed using the fluorescein isothiocyanate (FITC) channel, whereas PI, TMRM and Rhod-2 fluorescence were examined using the PE channel; both forward and side scatters were used to eliminate cellular fragments. Following treatment, a portion of cells were also fixed with $10 \%$ PBS-buffered formaldehyde with $0.1 \%$ Triton X-100 for $10 \mathrm{~min}$, then stained with $4^{\prime}, 6-$ diamidino-2-phenylindole (DAPI) (blue) and Fluo-3/AM (green) or Rhod-2 (red). Fluorescent images were visualized through confocal laser scanning microscopy as described previously. $^{40}$

TEM Observation on Cell Samples. After treatment with REE NPs at $20 \mu \mathrm{g} / \mathrm{mL}$ for $6 \mathrm{~h}$, cells were harvested and fixed in $2.5 \%$ glutaraldehyde for $2 \mathrm{~h}$, then washed with PBS buffer. Staining was performed using $1 \% \mathrm{OsO}_{4}$ for $1 \mathrm{~h}$, prior to dehydration of fixed and stained cells using alcohol (40, 50, 70, $80,90,95$ or $100 \%$ ethanol). Cells were then submerged in propylene oxide for two $30 \mathrm{~min}$ cycled and were then embedded in beem capsules containing pure resin. Blocks were hardened at $70{ }^{\circ} \mathrm{C}$ for a 2-day period, then $70 \mathrm{~nm}$ sections were cut and stained with $1 \%$ lead citrate and $0.5 \%$ uranyl acetate, prior to examination using a JEOL JEM 2010F highresolution transmission electron microscope (Hitachi Scientific Instruments, Japan).

Western Blot Analysis. The supernatant of cellular lysates was $(20 \mu \mathrm{g})$ subjected to both sodium dodecyl sulfate polyacrylamide gel electrophoresis (SDS-PAGE) and Western blotting, according to established protocols, as previously described. ${ }^{40}$ Western blotting signals were detected using a BIO-RAD ChemiDoc XRS chemiluminescence system (BioRad Inc., USA).

Statistical Analysis. One-way analysis of variance (ANOVA) was utilized for the analysis of mean differences between two or more treated groups and the untreated control group, whereas the differences between the two groups were determined using the two-tailed Student's $t$ test. Data are shown in mean \pm standard deviation (SD), and $p<0.05$ was considered statistically significant.

\section{RESULT AND DISCUSSION}

Characterization of REE NPs. To compare the cytotoxicity, REE NPs with varying elements were selected, including $\mathrm{nLa}_{2} \mathrm{O}_{3}, \mathrm{nEu}_{2} \mathrm{O}_{3}, \mathrm{nDy}_{2} \mathrm{O}_{3}$ and $\mathrm{nYb}_{2} \mathrm{O}_{3}$. The detailed physicochemical characterization of the selected REE NPs (Figure S2 and Table S2) showed that average primary REE NP diameters ranged from 21.3 to $58.8 \mathrm{~nm}$. These materials were dissolved in DMEM for cellular treatment and the hydrodynamic diameters of REE NPs were also assayed in 
(A)

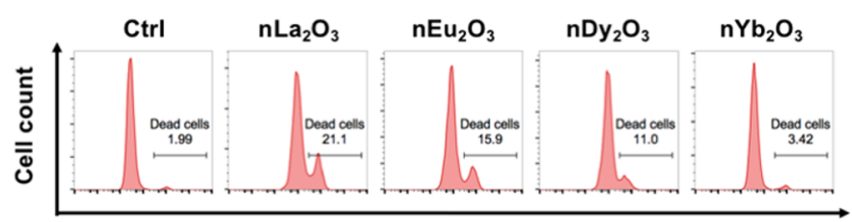

PI fluorescence intensity
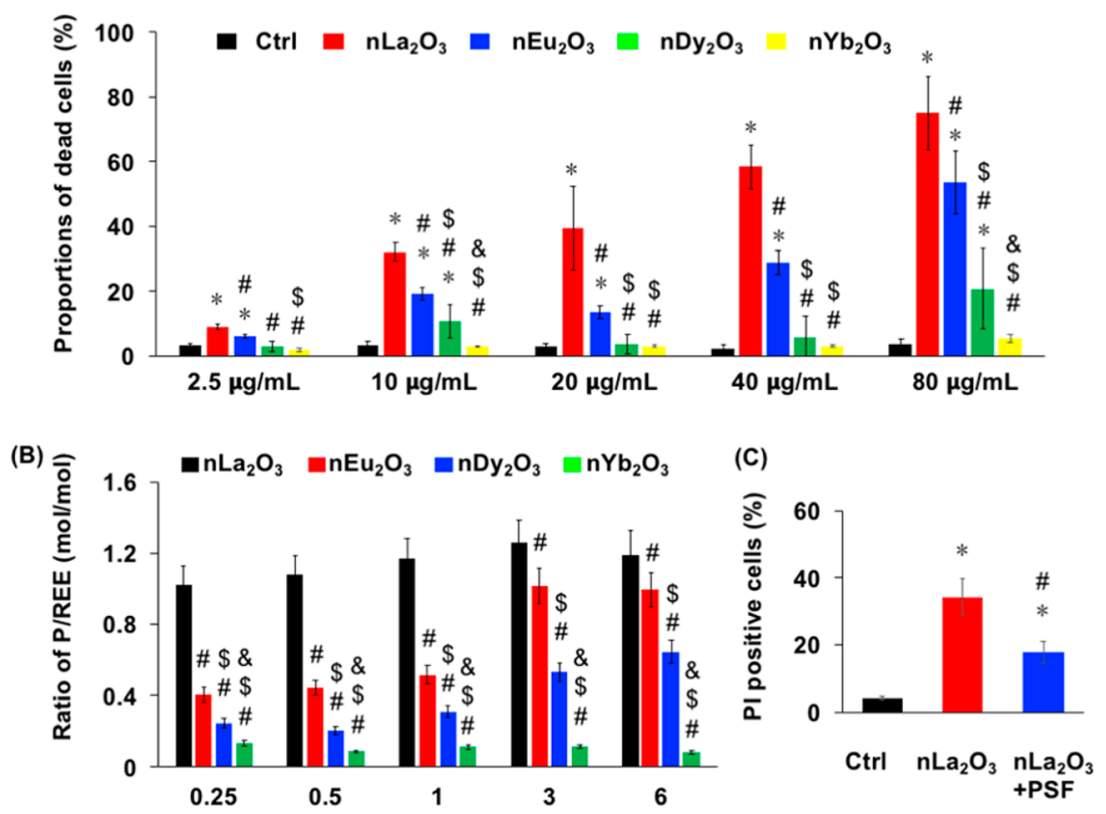

Figure 1. (A) Representative flow cytometrical analysis of J774A.1 macrophages. Percentages of dead cells in J774A.1 cells. (B) Dynamic monitoring of the transformation process of REE NPs suspended in PSF at $40 \mu \mathrm{g} / \mathrm{mL}$ for $0.25,0.5,1,3$ or $6 \mathrm{~h}$. Ratios of between phosphates concentration and REE levels. (C) Cell death was evaluated with PI staining $24 \mathrm{~h}$ after $20 \mu \mathrm{g} / \mathrm{mL} \mathrm{nLa}_{2} \mathrm{O}_{3}$ treatment with or without PSF. $n=3$ per group; * versus ctrl group, \# versus $\mathrm{nLa}_{2} \mathrm{O}_{3}$ group, $\$$ versus $\mathrm{nEu}_{2} \mathrm{O}_{3}$, \& versus $\mathrm{nDy}_{2} \mathrm{O}_{3}$ group. *, \#, $\$$ or \& represents $p<0.05$.

DMEM, showing that most nanoparticles formed aggregates with hydrodynamic diameters of 299.1-544.9 nm (Table S2). XPS analysis confirmed the chemical properties of $\mathrm{nLa}_{2} \mathrm{O}_{3}$, $\mathrm{nEu}_{2} \mathrm{O}_{3}, \mathrm{nDy}_{2} \mathrm{O}_{3}$ and $\mathrm{nYb}_{2} \mathrm{O}_{3}$ (Figure S3), whereas REE NP surface group analysis was also performed using FT-IR spectra. As shown in Figure S4, the FT-IR spectra demonstrated that the selected REE NPs possessed similar surface characteristics, as characterized by the common peak positions observed for $\mathrm{O}-\mathrm{H}$ groups $\left(3430 \mathrm{~cm}^{-1}\right), \mathrm{C}-\mathrm{H}$ groups $\left(2914 \mathrm{~cm}^{-1}\right), \mathrm{C}=\mathrm{O}$ groups $\left(1730 \mathrm{~cm}^{-1}\right)$ and $\mathrm{C}-\mathrm{O}$ groups $\left(1105 \mathrm{~cm}^{-1}\right){ }^{47,48}$ The presence of these functional groups on the surface of REE NPs, confirmed the formation of hydroxides and carbonates due to the reaction of REE NPs with ambient water and/or carbon dioxide. ${ }^{49}$

Sequestering of Phosphates from Cellular Biomolecules Involves the Cell Death. As shown in Figure S5, using PI as a cell membrane impermeable indicator, ${ }^{50}$ we first screened the cytotoxicity of REE NPs on J774A.1 macrophages and Hep1-6 hepatocytes as representative cell models. ${ }^{34}$ $\mathrm{nLa}_{2} \mathrm{O}_{3}, \quad \mathrm{nEu}_{2} \mathrm{O}_{3}$ and $\mathrm{nDy}_{2} \mathrm{O}_{3}$ triggered dramatic high population of death cells of macrophages, whereas displayed no toxicity on hepatocytes. Previous studies have demonstrated that liver is a major deposition site for nanomaterials, ${ }^{38}$ due to the high ability to remove toxin or particles from blood flow through the liver. Specialized macrophages such as Kupffer cells and hepatocytes are the two dominant cell types in the liver. The findings of the present study, show that $\mathrm{nLa}_{2} \mathrm{O}_{3}, \mathrm{nEu}_{2} \mathrm{O}_{3}$ and $\mathrm{nDy}_{2} \mathrm{O}_{3}$ showed cytotoxicity to J774A.1 macrophages but displays no effect on the survival of hepatocytes.
We therefore further focused our investigation on the cytotoxicity of REE NPs on macrophages. As shown in Figure $1 \mathrm{~A}$, there was a significant difference observed in the cytotoxicity caused by the four different REE NPs, with the most toxic material being $\mathrm{nLa}_{2} \mathrm{O}_{3}$, which induced $75.1 \%$ cell death at $80 \mu \mathrm{g} / \mathrm{mL}$, as compared to the untreated control ( $p<$ $0.05) . \mathrm{nEu}_{2} \mathrm{O}_{3}$ and $\mathrm{nDy}_{2} \mathrm{O}_{3}$ displayed significantly less toxicity, inducing $53.5 \%$ and $20.7 \%$ cell death respectively, at the highest exposure dose (Figure $1 \mathrm{~B}, p<0.05$ ). Conversely, $\mathrm{nYb}_{2} \mathrm{O}_{3}$ exerted only a negligible effect on cell survival (Figure 1A). To investigate these varying cytotoxic effects induced by different REE NPs, cell death was also assessed using the CellTox assay, ${ }^{45}$ where dead cells were stained with a green fluorescent dye once the permeability of its cell membrane is sufficiently increased. As shown in Figure S6, a significant dose- and timedependent increase in the intracellular fluorescence intensity of J774A.1 cell was observed $(p<0.05)$. After $12 \mathrm{~h}$ exposure, 80 $\mu \mathrm{g} / \mathrm{mL} \mathrm{nLa}_{2} \mathrm{O}_{3}$ induced up to a 4-fold increase in relative fluorescent intensity as compared to control cells, showing the highest level of cytotoxicity (Figure $\mathrm{S} 6, p<0.05$ ). $\mathrm{nEu}_{2} \mathrm{O}_{3}$ and $\mathrm{nDy}_{2} \mathrm{O}_{3}$ induced an approximately 2 -fold and 1-fold increase in intracellular fluorescence intensity, respectively (Figure S6, $p<$ 0.01 ). Conversely, $\mathrm{nYb}_{2} \mathrm{O}_{3}$ did not induce any increase in intracellular fluorescence intensity, even at the highest concentration (Figure S6, $p>0.05$ ). The findings of the present study, show that cytotoxicity is induced by toxic REE NPs including $\mathrm{nLa}_{2} \mathrm{O}_{3}, \mathrm{nEu}_{2} \mathrm{O}_{3}$ and $\mathrm{nDy}_{2} \mathrm{O}_{3}$ on to J774A.1 macrophages, and significant variations in cytotoxicity can be seen among REE NPs containing different REEs. 
(A)

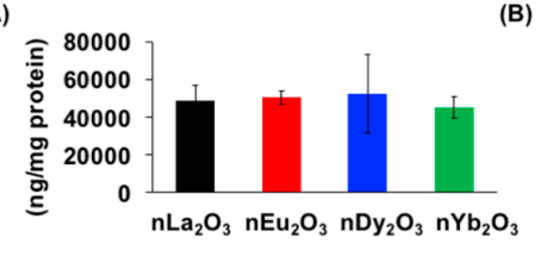

(C)

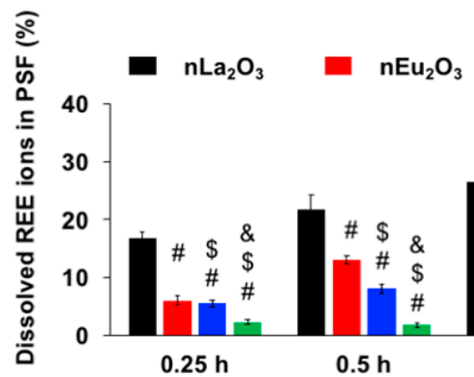

(D)

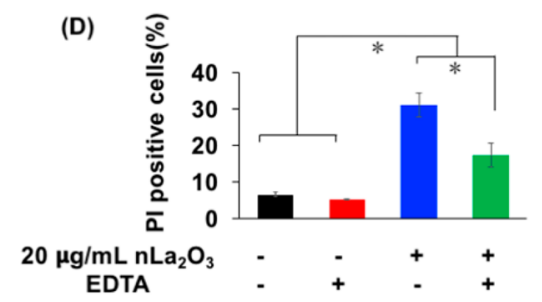

(B)

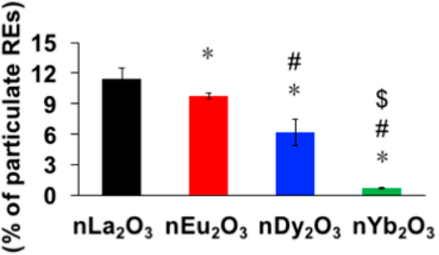

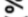

(E)

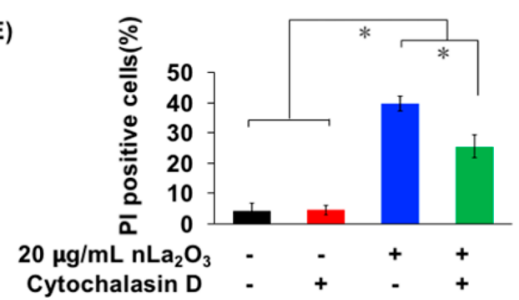

Figure 2. Cellular uptake of REE NPs and their dissolution within cells. (A) Total intracellular RE levels in cells after treatment with REE NPs at 20 $\mu \mathrm{g} / \mathrm{mL}$ for $6 \mathrm{~h}$. Cells were lysed and the total intracellular RE concentrations were determined by ICP-MS. (B) Concentrations of dissolved RE in cells. Cells were lysed and dissolved REE ions in the suspensions were measured using ICP-MS. (C) Rate of released dissolved REE ions by REE NPs after PSF incubation. (D) PI-positive cells for J774A.1 cells $24 \mathrm{~h}$ after $\mathrm{nLa}_{2} \mathrm{O}_{3}$ treatment at $20 \mu \mathrm{g} / \mathrm{mL}$ with or without cytochalasin D. (E) Cell death was determined with PI staining $24 \mathrm{~h}$ after $\mathrm{nLa}_{2} \mathrm{O}_{3}$ treatment at $20 \mu \mathrm{g} / \mathrm{mL}$ with or without EDTA preincubation. $n=3$ per group; $*$ versus ctrl group, \# versus $\mathrm{nLa}_{2} \mathrm{O}_{3}$ group, $\$$ versus $\mathrm{nEu}_{2} \mathrm{O}_{3}$, \& versus $\mathrm{nDy}_{2} \mathrm{O}_{3}$ group. *, \#, $\$$ or \& represents $p<0.05$.

The interaction of REE NPs with phosphates in plasma membrane are considered to be one of the causes for biological membranes damage. ${ }^{9,13}$ In order to investigate the ability to sequester cellular phosphates, the amount of phosphates adsorbed on the REE NPs was compared among different REE NPs. We incubated REE NPs with PSF to evaluate the ability to form REE NP-phosphates complex. ${ }^{44}$ We then characterized the molar ratio of particulate associated $\mathrm{P} / \mathrm{REE}$ $(\mathrm{mol} / \mathrm{mol})$ for each REE NPs. As shown in Figure $1 \mathrm{~B}, \mathrm{nLa}_{2} \mathrm{O}_{3}$, $\mathrm{nEu}_{2} \mathrm{O}_{3}$ and $\mathrm{nDy}_{2} \mathrm{O}_{3}$ appeared to sequester phosphates in PSF, but presented with different $\mathrm{P} / \mathrm{REE}$ dynamics upon exposure to PSF. $\mathrm{nLa}_{2} \mathrm{O}_{3}$ displayed the highest ability to sequester phosphates after $15 \mathrm{~min}$, with the significantly highest $\mathrm{P} / \mathrm{REE}$ ratios $(\mathrm{mol} / \mathrm{mol})$ of 1.07 and 1.26 , at $15 \mathrm{~min}$ and $6 \mathrm{~h}$, respectively. $\mathrm{nEu}_{2} \mathrm{O}_{3}$ presented a weaker affinity to react with phosphates, with the initial $\mathrm{P} / \mathrm{REE}$ ratio of 0.44 at $15 \mathrm{~min}$, increasing to 1.31 at $6 \mathrm{~h}$. The $\mathrm{P} / \mathrm{REE}$ ratio established for $\mathrm{nDy}_{2} \mathrm{O}_{3}$ was 0.2 at $15 \mathrm{~min}$, elevating to 0.72 at $6 \mathrm{~h}$, notably lower than that of $\mathrm{nLa}_{2} \mathrm{O}_{3}$ and $\mathrm{nEu}_{2} \mathrm{O}_{3}$. The $\mathrm{P} / \mathrm{RE}$ ratio of $\mathrm{nYb}_{2} \mathrm{O}_{3}$ was initially around 0.08 and remained constant for the $6 \mathrm{~h}$ exposure period. Therefore, the ranking of ability to form PREE complexes is $\mathrm{La}>\mathrm{Eu}>\mathrm{Dy}>\mathrm{Yb}$, with $\mathrm{nYb}_{2} \mathrm{O}_{3}$ showing a very limited ability to sequester phosphates. The findings of these in vitro incubation experiments further confirm the ability of toxic REEs and phosphates to form complexes and the dephosphorylation of cell membrane may involve the membrane damage. To establish the possible correlation of the activity in P-REE complexes formation and cytotoxicity, we performed regression analysis (Figure S7A). Positive trends were observed for all the REE NPs $(R=0.928, p<0.05)$. Therefore, it may be assumed that the ability in REE NPs to form complex with phosphates decreased with higher REE atomic number, and the ability of REE NPs to complex phosphates decreased with higher REE atomic number.

To assess the role of REE NP-induced dephosphorylation on cell death, $\mathrm{nLa}_{2} \mathrm{O}_{3}$ was selected as representative REE NPs. For the investigation of the cytotoxicity of $\mathrm{nLa}_{2} \mathrm{O}_{3}$ as the representative material, $20 \mu \mathrm{g} / \mathrm{mL}$ was selected because the concentration higher than $20 \mu \mathrm{g} / \mathrm{mL}(40$ or $80 \mu \mathrm{g} / \mathrm{mL})$ possess dramatic toxicity which could induce cell detached from the tissue culture dish. Therefore, $20 \mu \mathrm{g} / \mathrm{mL} \mathrm{nLa}_{2} \mathrm{O}_{3}$ was incubated in $10 \mathrm{mM}$ PSF $\left(\mathrm{pH} \mathrm{7.4)}\right.$ ) at $37{ }^{\circ} \mathrm{C}$ for $24 \mathrm{~h}$, resulting in cytotoxicity being reduced by $60 \%$, as compared to treated cells without PSF preincubation (Figure 1C, $p<0.05$ ). These results together suggest the sequestration of phosphates induces cell membrane damage cell death.

Cell Uptake of Toxic REE NPs Involves the Cell Death. We then identified whether cellular uptake of REE NPs was responsible for the observed cytotoxicity. As shown in Figure 2A, ICP-MS results showed that intracellular particulate REE mass ranged from 45.1 to $52.3 \mu \mathrm{g} / \mathrm{mg}$ protein, with no significant difference detectable in total REE mass among Dy, $\mathrm{Eu}, \mathrm{La}$ and $\mathrm{Yb}$ materials $(p>0.05)$. To identify the effects induced by extracellular dissolved RE ions released by REE NPs, the mass of dissolved REE ions in DMEM medium were determined, showing approximately an average of $2.7 \%$ dissolution after $24 \mathrm{~h}$ incubation (Figure S8). This concentration of dissolved ions was then applied to toxicity assays to assess cell death. According to the dissolved ion concentrations, J774A. 1 cells were treated with dissolved $\mathrm{La}\left(\mathrm{NO}_{3}\right)_{3}, \mathrm{Eu}\left(\mathrm{NO}_{3}\right)_{3}$, $\mathrm{Dy}\left(\mathrm{NO}_{3}\right)_{3}$ or $\mathrm{Yb}\left(\mathrm{NO}_{3}\right)_{3}$, containing dissolved $\mathrm{La}(0.44 \mu \mathrm{g} /$ $\mathrm{mL}), \mathrm{Eu}(0.55 \mu \mathrm{g} / \mathrm{mL}), \mathrm{Dy}(0.56 \mu \mathrm{g} / \mathrm{mL})$ or $\mathrm{Yb}(0.28 \mu \mathrm{g} / \mathrm{mL})$ 
(A)
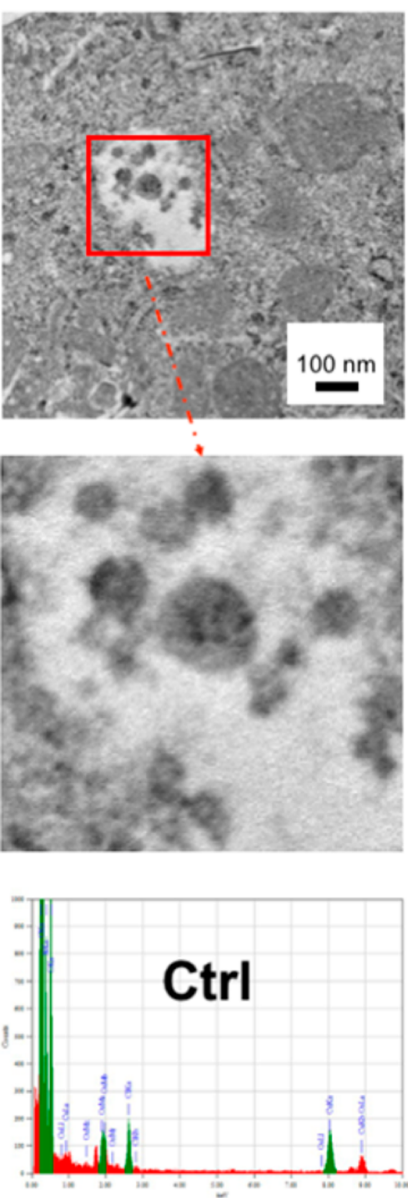

$\mathrm{nLa}_{2} \mathrm{O}_{3}$
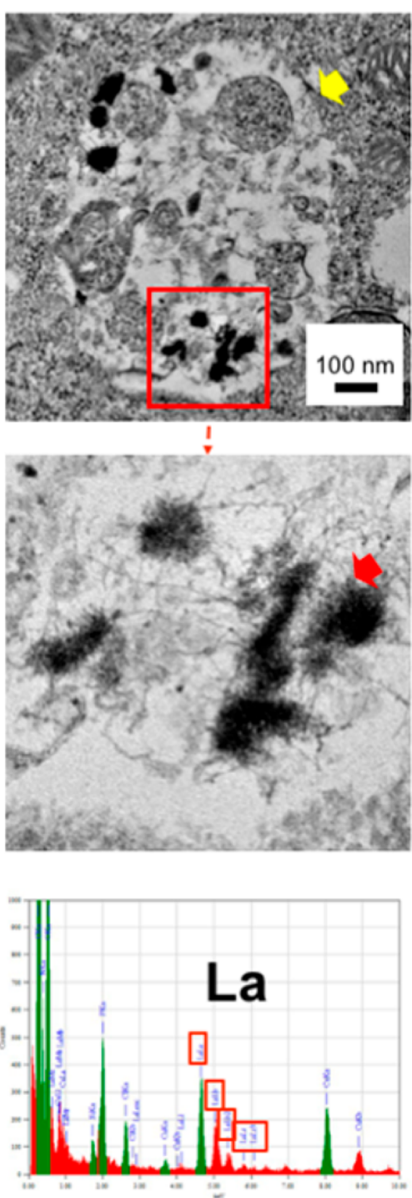

(B)

Ctrl

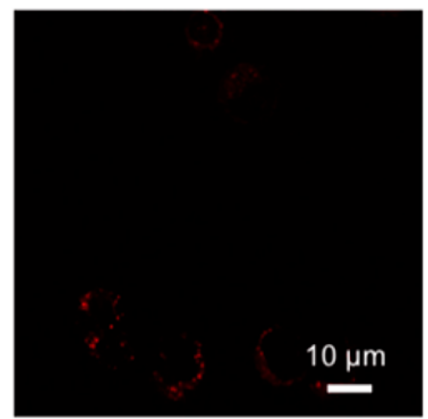

(C)

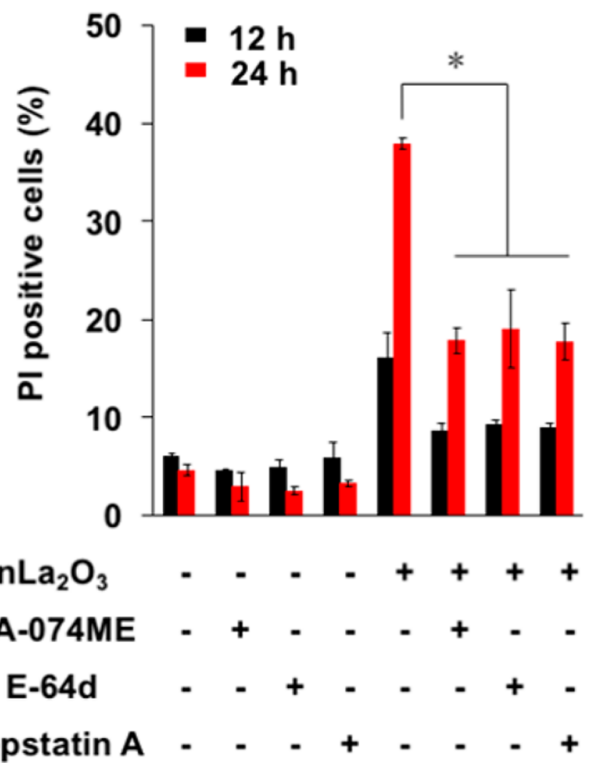

Figure 3. REE NPs induced cell death through LMP. (A) Particle uptake in J774A.1 cells were assessed after $6 \mathrm{~h}$ treatment with $20 \mu \mathrm{g} / \mathrm{mL} \mathrm{nLa}_{2} \mathrm{O}_{3}$ through TEM. Yellow arrows denote enlarged lysosomes. Red arrows denote transformed $\mathrm{nLa}_{2} \mathrm{O}_{3}$. (B) After incubation for $6 \mathrm{~h}$, cells were stained with Magic Red to characterize Cathepsin B location through confocal microscopy. (C) Cell death was evaluated by PI staining after $20 \mu \mathrm{g} / \mathrm{mL}$ $\mathrm{nLa}_{2} \mathrm{O}_{3}$ treatment for $24 \mathrm{~h}$ with or without the preincubation of cathepsins inhibitors. $n=3$ per group; $*$ versus ctrl group. $*$ represents $p<0.05$.

ions in medium. Following $24 \mathrm{~h}$ of incubation, no cell death was observed in any REE NP exposure group (data not shown), allowing toxicity of extracellular REEs to be discounted as a cause of cytotoxicity. ${ }^{45}$

It has been documented that intracellular metal ion release upon exposure to and accumulation of nanomaterials largely dictates the differing biological effects observed among and their extracellular ions. ${ }^{44,51}$ Therefore, the amount of dissolved REE ions were measured from supernatants from the digested total cell lysates after REE NP exposure, then analyzed using ICP-MS (Figure 2B). The relative abundance of the intracellular dissolved ions of $\mathrm{nLa}_{2} \mathrm{O}_{3}, \mathrm{nEu}_{2} \mathrm{O}_{3}$ and $\mathrm{nDy}_{2} \mathrm{O}_{3}$ were $11.5 \%(6.26 \mu \mathrm{g} / \mathrm{mg}$ protein), 9.7\% (5.4 $\mu \mathrm{g} / \mathrm{mg}$ protein) and $6.2 \%(3.6 \mu \mathrm{g} / \mathrm{mg}$ protein $)$, respectively. It is of note that $\mathrm{nYb}_{2} \mathrm{O}_{3}$ showed only minor levels of dissolution, releasing $0.7 \%$ of ions intracellularly $(0.3 \mu \mathrm{g} / \mathrm{mg}$ protein) (Figure $2 \mathrm{~B})$.

To determine whether the concentration of intracellular dissolved REEs was driven by interaction between REE NPs with membrane phosphates, we incubated REE NPs with PSF and monitored the dissolved REE ion concentrations by determination of REEs in suspensions following PSF incubation with REE NPs. $\mathrm{nLa}_{2} \mathrm{O}_{3}, \mathrm{nEu}_{2} \mathrm{O}_{3}$ and $\mathrm{nDy}_{2} \mathrm{O}_{3}$ were found to increase the levels of dissolved REE ions in PSF (Figure 2C). The proportion of dissolved REEs released in PSF from $\mathrm{nLa}_{2} \mathrm{O}_{3}, \mathrm{nEu}_{2} \mathrm{O}_{3}$ and $\mathrm{nDy}_{2} \mathrm{O}_{3}$ were $17.3 \%, 6.4 \%$ and $5.2 \%$ at $15 \mathrm{~min}$, increasing to $34.1 \%, 26.3 \%$ and $15.1 \%$ at $6 \mathrm{~h}$, respectively. Conversely, $\mathrm{nYb}_{2} \mathrm{O}_{3}$ released only $0.8 \%$ dissolved ions, showing a significantly lower ion release potential. Therefore, the order of dissolved rates of REEs was La $>\mathrm{Eu}$ $>\mathrm{Dy}>\mathrm{Yb}$, with a similar trend to the ability to for P-REEs complexity. These results indicate the release of dissolved ions from REE NPs is because the interaction between REEs and phosphates. To further evaluate the relation between cell death and dissolved ions levels, the regression analysis was performed. The positive trend was observed between the cell death percentages and the rate of dissolved REEs (Figure S7B, $R=$ 0.987, $p<0.05$ ). To further define the effects of dissolved La ions on cell death, $\mathrm{nLa}_{2} \mathrm{O}_{3}$ was selected to expose J774A.1 cells with or without EDTA, as a chelating agent for dissolved La ions (stability constant $=15.46$ ) and therefore inhibit their biological reaction with phosphates. As shown in Figure 2D, 50 $\mu \mathrm{M}$ EDTA reduced cell death by $30 \%$, compared to treated cells without EDTA pretreatment $(p<0.05)$. These findings together demonstrate the intracellular dissolved toxic REE ions plays a role in the cell death. To investigate the involvement of cellular uptake in REE NP toxicity, cells were preincubated with cytochalasin $\mathrm{D}$, an inhibitor of actin polymerization, for $2 \mathrm{~h}$ prior to $\mathrm{nLa}_{2} \mathrm{O}_{3}$ exposure. Cell death induced by $\mathrm{nLa}_{2} \mathrm{O}_{3}$ was 
(A)

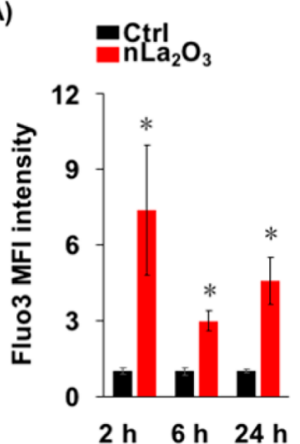

(D)

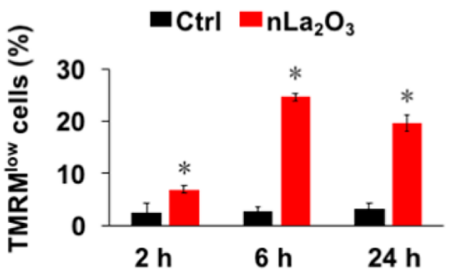

(F)

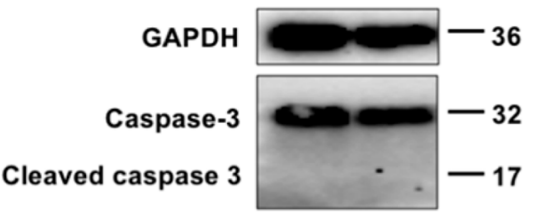

$(20 \mu \mathrm{g} / \mathrm{mL} 12 \mathrm{~h}) \mathrm{Ctrl} \mathrm{nLa}_{2} \mathrm{O}_{3}$

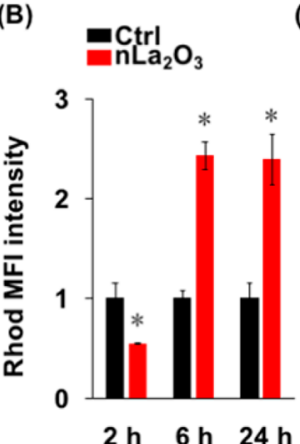

(C)

Ctrl

$\mathrm{nL} \mathrm{a}_{2} \mathrm{O}_{3}$

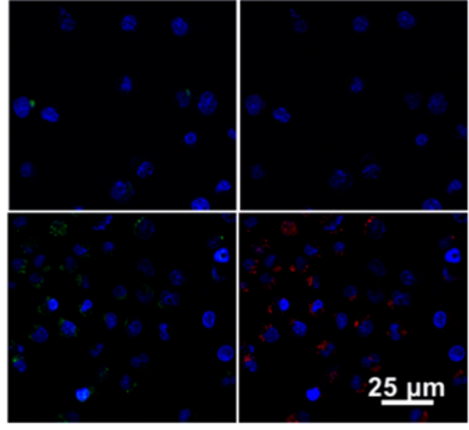

Fluo-3/AM

Rhod-2

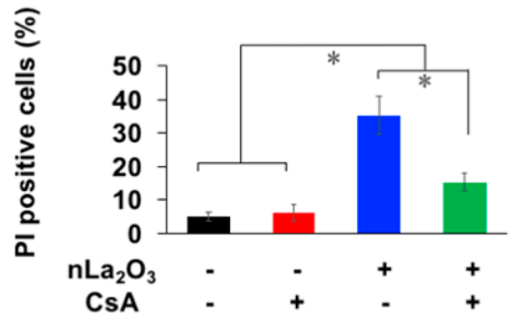

(G)

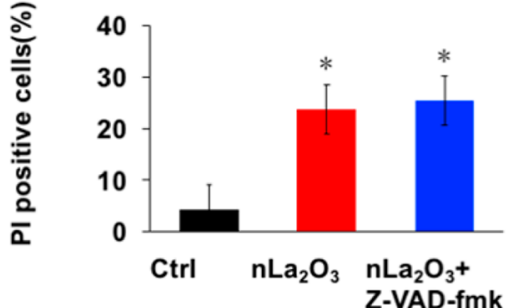

Figure 4. Mitochondrial and autophagic flux inhibition contributed to REE NP-induced cell death. After 2,6 and $24 \mathrm{~h}$ of incubation with $20 \mu \mathrm{g} / \mathrm{mL}$ $\mathrm{nLa}_{2} \mathrm{O}_{3}$, cells were stained by Fluo-3/AM (A) or Rhod-2 (B), followed by FACS. (C) Cellular staining with Fluo-3/AM, Rhod-2 and DAPI (blue) in cells upon $\mathrm{nLa}_{2} \mathrm{O}_{3}$ treatment at $20 \mu \mathrm{g} / \mathrm{mL}$ for $6 \mathrm{~h}$. Cells were examined with confocal microscopy. Two colors are shown individually or merged together. (D) After 2, 6 and $24 \mathrm{~h}$ of incubation with $20 \mu \mathrm{g} / \mathrm{mL}$ REE NPs, alteration in membrane potential was evaluated by TMRM staining followed by FACS. (E) Cell death was assessed with PI staining at $24 \mathrm{~h}$ after $20 \mu \mathrm{g} / \mathrm{mL} \mathrm{nLa}_{2} \mathrm{O}_{3}$ treatment with or without CsA. (F) Western blot analysis of caspase 3 activation in J774A.1 cells with $\mathrm{nLa}_{2} \mathrm{O}_{3}$ treatment at $20 \mu \mathrm{g} / \mathrm{mL}$ for $12 \mathrm{~h}$. (G) Cell death $24 \mathrm{~h}$ after $20 \mu \mathrm{g} / \mathrm{mL} \mathrm{nLa}{ }_{2} \mathrm{O}_{3}$ treatment with or without Z-VAD-fmk. $n=3$ per group; * versus ctrl group. * represents $p<0.05$.

mitigated due to the presence of the inhibitor, whereas cytochalasin D itself showed no significant effect on cell viability, demonstrating that REE NP-induced cell death was dependent on cellular REE NP uptake (Figure 2E, $p<0.05$ ).

Lysosomal Enzyme Release into Cytosol Involves the Cell Death. To further characterize the intracellular accumulation of REE NPs, TEM imaging was performed to characterize intracellular REE NP localization. $\mathrm{nLa}_{2} \mathrm{O}_{3}$, $\mathrm{nEu}_{2} \mathrm{O}_{3}, \mathrm{nDy}_{2} \mathrm{O}_{3}$ and $\mathrm{nYb}_{2} \mathrm{O}_{3}$ particles were predominantly localized in lysosomes (Figure S9). With $\mathrm{nLa}_{2} \mathrm{O}_{3}$ as a representative material, a sea urchin-like formation was observed in lysosome earlier than $6 \mathrm{~h}$ (Figure 3A), suggesting REE NP transformation in lysosomes, in agreement with previously reported results. ${ }^{52}$ Energy dispersive X-ray (EDX) data confirmed the REEs within lysosome (Figure 3A, Figure S9). $\mathrm{nLa}_{2} \mathrm{O}_{3}$ accumulation resulted in the apparent enlargement of lysosomes, suggesting lysosomal injury had occurred. Conversely, control cells showed no significant disturbance to lysosomal size (Figure 3A, Figure S9). Lysosomes are acidic organelles containing a wide range of hydrolytic enzymes that have significant roles in intracellular protein recycling. Cathepsins are dominant and highly active hydrolytic enzymes, ${ }^{38}$ with various cathepsins been classified as cysteine proteases. $^{53}$ Once cathepsins released into the cytosolic compartment, they remain active for some time under neutral $\mathrm{pH}$ conditions, triggering downstream signaling pathways. ${ }^{54}$ LMP-led cytosolic translocation has been linked to the cell death, ${ }^{55}$ and the degree of LMP induced by REE NPs was assessed using the cathepsin substrate Magic Red, which is cleaved by cathepsin B. ${ }^{53,56,57}$ Therefore, to determine whether the LMP take place, we monitored the localization of cathepsin $\mathrm{B}$ at $6 \mathrm{~h}$, and as shown in Figure 3B, concentrated red dots appeared within the cytosol, suggesting of the presence of cathepsins in lysosomes. The intensity of red color in cytosolic compartment in $\mathrm{nLa}_{2} \mathrm{O}_{3}$-treated cells was quantitatively greater than that in control cells, indicating that $\mathrm{nLa}_{2} \mathrm{O}_{3}$ has a greater capability to disrupt cell membrane integrity than the other REE NPs assessed. To assess the implication of LMP and the consequential release of cathepsins on cell viability, J774A.1 cells were exposed to $\mathrm{nLa}_{2} \mathrm{O}_{3}$ in the presence or absence of a range of cathepsin inhibitors, including CA-074Me, E64-d and pepstatin A. As shown in Figure 3C, cell death was significantly inhibited by approximately $50.0 \%$ of cathepsin inhibitors assessed, suggesting an important role of cytosolic cathepsins in REE NP induced cell death. The observed toxicity was highly 
dependent on the ability of REE NPs to sequester phosphates from lysosomal membranes and the resulting degree of LMP.

Autophagy is a major mechanism used by cells to clear damaged organelles from intracellular compartments, transporting them to lysosomes for digestion. ${ }^{58-60}$ The ratio ofcytosolic form of LC3/LC3-phosphatidylethanolamine conjugate (LC3-II/LC3-I) was assessed using Western blot analysis and as shown in Figure S10A, a significant 3.7-fold increased ratio of LC3-II/LC3-I was observed in cells treated with $\mathrm{nLa}_{2} \mathrm{O}_{3}$, as compared to the control group. This indicates that the impaired autophagy flux occurs due to disruption to the fusion between autosome and lysosome. ${ }^{44,61}$ With a reporter cell (RAW-Difluo mLC3 Cells, invivogen), we confirmed the blockage of autophagic flux by $\mathrm{nLa}_{2} \mathrm{O}_{3}$ (Figure S10B) Therefore, these results suggest that the attenuated autophagic flux was another side effect of LMP. Given the importance of clearance of aged and damaged cellular components to the survival of cells, the attenuated autophagic flux may enhance the cell death. ${ }^{44}$ We then test whether rapamycin, as an agent to stimulate autophagy, could rescue the cell death of J774A.1 cells. As shown in Figure S10C, the promotion of autophagic flux showed no effect on cell death, suggesting autophagyassociated cell death is not involved in cell death.

Role of Intracellular Calcium in REE NP-Induced Cell Death. Intracellular $\mathrm{Ca}^{2+}$ flux was one of important regulator for cell death. ${ }^{62}$ As shown in Figure 4A, increased intensity of Fluo-3A within cells suggests that the concentration of $\left[\mathrm{Ca}^{2+}\right]_{\mathrm{I}}$ significantly increased in cells exposed to $\mathrm{nLa}_{2} \mathrm{O}_{3}$. We used Rhod-2 fluorescence as an indicator for mitochondrial calcium $\left(\left[\mathrm{Ca}^{2+}\right]_{\mathrm{M}}\right)$, and found that $\mathrm{nLa}_{2} \mathrm{O}_{3}$ induced a significant 1.5 -fold increase in Rhod-2 fluorescence intensity as compared to the control group (Figure 4B, $p<0.05$ ) at both 6 and $24 \mathrm{~h}$. The increase in $\left[\mathrm{Ca}^{2+}\right]_{\mathrm{I}}$ and $\left[\mathrm{Ca}^{2+}\right]_{\mathrm{M}}$ was also confirmed by confocal microscopy, observing enhanced intensity of both intracellular Fluo-3/AM and Rhod-2 (Figure 4C). We then evaluated the mitochondrial potential $\left(\Delta \Psi_{\mathrm{m}}\right)$ with TMRM to reflect the health status of mitochondria. As shown in Figure 4D, comparing with control cells, the proportion of cells with TMRM $^{\text {low }}$ intensity increased to $6.8 \%, 24.7 \%$ and $19.6 \%$ at $2 \mathrm{~h}$, 6 and $24 \mathrm{~h}(p<0.05)$, respectively, suggesting a reduction in $\Delta \Psi_{\mathrm{m}}$ due to $\mathrm{nLa}_{2} \mathrm{O}_{3}$ exposure. Mitochondria provides buffering against the overload of intracellular $\left[\mathrm{Ca}^{2+}\right]_{\mathrm{I}}$. The elevation of $\left[\mathrm{Ca}^{2+}\right]_{\mathrm{M}}$ is a key regulator of mitochondrial function and is known to cause permeability transition pore (PTP) formation. $^{38,63-65}$ To assess the occurrence of this, before REE NP exposure, cells were treated with CsA, which inhibits PTP by binding to $\mathrm{Ca}^{2+}$. As shown in Figure 4E, pretreatment with CsA reduced cell death from $19.4 \%$ to $6.9 \%$, indicating that CsA can successfully inhibit the cytotoxicity of $\mathrm{nLa}_{2} \mathrm{O}_{3}$. Because mitochondria could regulate cell death through both apoptosis and necrosis, we then evaluated the cleavage of caspase 3 as a representative caspase to regulate apoptosis to determine whether cell apoptosis is involved. Following $\mathrm{nLa}_{2} \mathrm{O}_{3}$ exposure, Western blot analysis showed no evidence of caspase 3 cleavage observed (Figure 4F). To further confirm this observation, we selected Z-VAD-fmk as the pan-caspase inhibitor, which could inhibit all types of caspases, and was frequently used for evaluation on the cell apoptosis. We found that Z-VAD-fmk did not inhibit $\mathrm{nLa}_{2} \mathrm{O}_{3}$-induced cell death (Figure 4G), indicating that cell death was due to necrosis but not caspase dependent apoptosis.

Environmental Implication. The extensive application of REEs is already a great concern for the effects on eco- environmental safety and human health due to the exposure to the human body through various exposure route. As the important role for clear the introduced nanoparticles by various routes, macrophages is more sensitive than the other cell type and responsible for the series side effects. With macrophage as a cell model, a dramatic variation was observed in the degree of cytotoxicity induced by different REE NPs, which was highly dependent on the types of REEs. The activity in phosphates sequestration induced by REE NPs is responsible the cell death which could induce both cell membrane damage and LMP (Figure 5). Previous studies have reported that the damage of

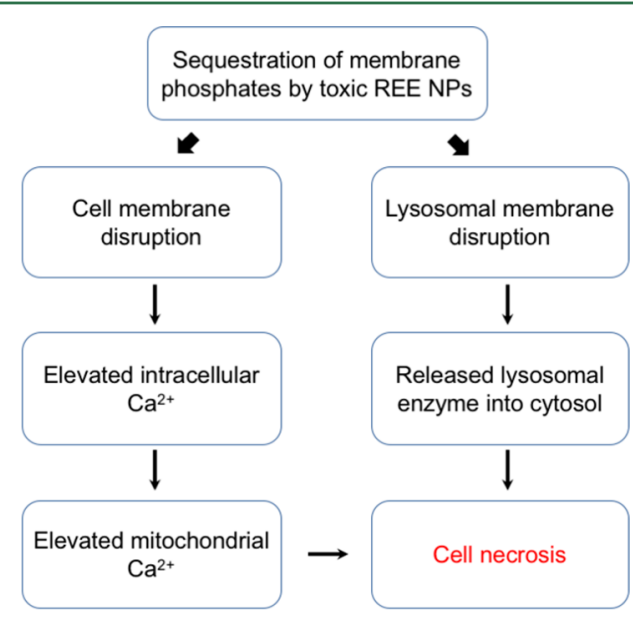

Figure 5. Schematic deciphering REE NP-induced cytotoxicity. The toxic REE NPs including $\mathrm{nLa}_{2} \mathrm{O}_{3}, \mathrm{nEu}_{2} \mathrm{O}_{3}$ and $\mathrm{nDy}_{2} \mathrm{O}_{3}$ induce the damage of cell membrane and leads to the increase in intracellular $\left[\mathrm{Ca}^{2+}\right]_{\mathrm{I}}$ and $\left[\mathrm{Ca}^{2+}\right]_{\mathrm{M}}$, and the resultant cell necrosis. Accumulated REE NPs in lysosome triggered LMP, leading to the release of cathepsins into cytosol, which also contributes cell death.

cell membrane could trigger the influx of intracellular calcium $\left(\left[\mathrm{Ca}^{2+}\right]_{\mathrm{I}}\right){ }^{62}$ LMP has also been demonstrated to govern the storage of intracellular calcium $\left(\left[\mathrm{Ca}^{2+}\right]_{\mathrm{I}}\right)$ and act as a regulator of cell death, triggering cell death through the release of $\mathrm{Ca}^{2+}$ from lysosome to cytosol compartment. ${ }^{63-66}$ Our results indicated that cell membrane or lysosomal membrane disruption could result in the elevation of $\left[\mathrm{Ca}^{2+}\right]_{I}$ and consequentially induce cell death. Despite mitochondrial responses to sequester $\left[\mathrm{Ca}^{2+}\right]_{\mathrm{I}}$, the sustained high $\mathrm{Ca}^{2+}$ concentrations result in PTP which promotes cell necrosis. Although the mechanism for REE NPs warrant further investigation, the elevation of $\left[\mathrm{Ca}^{2+}\right]_{\mathrm{I}}$ and $\left[\mathrm{Ca}^{2+}\right]_{\mathrm{M}}$ upon exposure to REE NPs has been unveiled in the current study. Caspase-3 was a predominant enzyme to regulate cell apoptosis, which has been frequently applied for the marker to evaluate the possible apoptosis of cells. We first applied this marker to determine whether macrophages undergo apoptosis upon $\mathrm{La}_{2} \mathrm{O}_{3}$ treatment. We also applied Z-VAD-fmk as an inhibitor to inactivate all kinds of caspases to confirm the conclusion that caspase-apoptosis was not involved in the cell death. We discussed this in detail in the manuscript. The fact that caspase inhibitor failed to rescue cell death suggested the cytotoxicity was not due to apoptosis. Upon normal autophagic flux, LC3-I is conjugated to LC3-II and delivered to autophagosomal membranes. Autophagosomes then fuse with lysosomes to form autolysosomes to degrade intra-autophagosomal components by lysosomal enzymes. Meanwhile, LC3-II in the autolysosomal lumen is degraded. Thus, the accumu- 
lation of LC3-II and LC3-I accumulation is applied as a surrogate for autophagy flux to elucidate the possible role of lysosomes in REE NP-induced cell death. ${ }^{61}$ In the current study, although the disruption of autophagic flux has been found, it showed no contribution to cell death. Therefore, our data together demonstrate that cell death of macrophages induced by REE NPs is because of necrosis, but not caspase dependent apoptosis or autophagy-associated cell death. These findings provide an in-depth insight into the mechanisms of cytotoxicity induced by exposure to a range of REE NPs and that element composition-associated toxicity profiles should be considered during the selection of REEs for use in the design of nanomaterials, such as with upconversion nanoparticles. Our findings also suggested the coating of REE NPs with phosphates could block the activity of REE NPs, providing higher safety of these materials. This method is also helpful for the treatment of waste REE NPs, through the blockage of surface activity with phosphates treatment. Also, upon incidental exposure to REE NPs such as inhalation of these materials in miners, suitable EDTA administration could relief the toxic of the inhaled REE NPs. As the widely application of REE NPs, our results would be useful for the risk assessment of the environmental safety and health upon exposure different types of REE NPs.

\section{ASSOCIATED CONTENT}

\section{S Supporting Information}

The Supporting Information is available free of charge on the ACS Publications website at DOI: 10.1021/acs.est.7b04231.

Linearity of La, Eu, Dy and $\mathrm{Yb}$ using ICP-MS; representative HRTEM image of the 4 kinds of REE NPs in the current study; XPS spectra of the selected REE NPs in the current study; FT-IR spectra of the selected REE NPs materials; percentages of dead cells in J774A.1 cells or Hep1-6 cells; heat map showing the relative intensity of intracellular fluorescence of J774A.1 cells after REE NPs treatment using the CellTox assay; relations between ratio of $\mathrm{P} / \mathrm{REE}$ and cell death or relations between dissolved REE ions and cell death; dissolution of rare earth ions in DMEM medium; particle uptake in J774A.1 cells were assessed after $6 \mathrm{~h}$ treatment with REE NPs through TEM and the energy dispersive $\mathrm{X}$-ray (EDX) data; autophagic flux analysis upon $\mathrm{nLa}_{2} \mathrm{O}_{3}$ treatment $(\mathrm{PDF})$

\section{AUTHOR INFORMATION}

Corresponding Author

*Guangbo Qu, Email: gbqu@rcees.ac.cn.

\section{ORCID $\odot$}

Ruibin Li: 0000-0001-6471-7658

Ligang Hu: 0000-0002-6213-4720

Jianbo Shi: 0000-0003-2637-1929

Qunfang Zhou: 0000-0003-2521-100X

Maoyong Song: 0000-0002-6776-4705

Bin Zhang: 0000-0002-1529-6356

Guangbo Qu: 0000-0002-5220-7009

Sijin Liu: 0000-0002-5643-0734

\section{Notes}

The authors declare no competing financial interest.

\section{ACKNOWLEDGMENTS}

This work was supported by the Strategic Priority Research Program of the Chinese Academy of Sciences (No. XDB14010400), and grants from the National Natural Science Foundation of China (No. 21527901 and 21577165).

\section{REFERENCES}

(1) Adachi, G.; Imanaka, N. The binary rare earth oxides. Chem. Rev. 1998, 98 (4), 1479-1514.

(2) Cassee, F. R.; van Balen, E. C.; Singh, C.; Green, D.; Muijser, H.; Weinstein, J.; Dreher, K. Exposure, Health and Ecological Effects Review of Engineered Nanoscale Cerium and Cerium Oxide Associated with its Use as a Fuel Additive. Crit. Rev. Toxicol. 2011, 41 (3), 213-229.

(3) Li, X.; Chen, Z.; Chen, Z.; Zhang, Y. A human health risk assessment of rare earth elements in soil and vegetables from a mining area in Fujian Province, Southeast China. Chemosphere 2013, 93 (6), $1240-1246$

(4) Sreedharan, R. S.; Ganesan, V.; Sudarsanakumar, C. P.; Bhavsar, K.; Prabhu, R.; Mahadevan Pillai, V. P. Highly textured and transparent RF sputtered $\mathrm{Eu}_{2} \mathrm{O}_{3}$ doped $\mathrm{ZnO}$ films. Nano Rev. 2015, 6 (1), 2675926765.

(5) Liu, Z.; Li, Z. H.; Liu, J. H.; Gu, S.; Yuan, Q. H.; Ren, J. S.; Qu, X. G. Long-circulating $\mathrm{Er}^{3+}$-doped $\mathrm{Yb}_{2} \mathrm{O}_{3}$ up-conversion nanoparticle as an in vivo X-Ray CT imaging contrast agent. Biomaterials 2012, 33 (28), 6748-6757.

(6) Miao, C.; Liu, T.; Zhu, Y. S.; Dai, Q. L.; Xu, W.; Xu, L.; Xu, S.; Zhao, Y.; Song, H. W. Super-intense white upconversion emission of $\mathrm{Yb}_{2} \mathrm{O}_{3}$ polycrystals and its application on luminescence converter of dye-sensitized solar cells. Opt. Lett. 2013, 38 (17), 3340-3343.

(7) Tegafaw, T.; Xu, W.; Ahmad, M. W.; Baeck, J. S.; Chang, Y.; Bae, J. E.; Chae, K. S.; Kim, T. J.; Lee, G. H. Dual-mode T1 and T2 magnetic resonance imaging contrast agent based on ultrasmall mixed gadolinium-dysprosium oxide nanoparticles: synthesis, characterization, and in vivo application. Nanotechnology 2015, 26 (36), 365102.

(8) Thomas, P. J.; Carpenter, D.; Boutin, C.; Allison, J. E. Rare earth elements (REEs): effects on germination and growth of selected crop and native plant species. Chemosphere 2014, 96, 57-66.

(9) Rambeck, W. A.; Wehr, U. Use of rare earth elements as feed additives in pig production. Pig News Inf. 2005, 26 (2), 41-47.

(10) Liang, T.; Zhang, S.; Wang, L.; Kung, H. T.; Wang, Y.; Hu, A.; Ding, S. Environmental biogeochemical behaviors of rare earth elements in soil-plant systems. Environ. Geochem. Health 2005, 27 (4), 301-311.

(11) Olias, M.; Ceron, J. C.; Fernandez, I.; De la Rosa, J. Distribution of rare earth elements in an alluvial aquifer affected by acid mine drainage: the Guadiamar aquifer (SW Spain). Environ. Pollut. 2005, 135 (1), 53-64.

(12) Wen, B.; Liu, Y.; Hu, X. Y.; Shan, X. Q. Effect of earthworms (Eisenia fetida) on the fractionation and bioavailability of rare earth elements in nine Chinese soils. Chemosphere 2006, 63 (7), 11791186.

(13) Fang, J.; Wen, B.; Shan, X. Q.; Wang, H. H.; Lin, J. M.; Zhang, S. Z. Evaluation of bioavailability of light rare earth elements to wheat (Triticum aestivum L.) under field conditions. Geoderma 2007, 141 (1-2), 53-59.

(14) Miao, L.; Ma, Y. L.; Xu, R. S.; Yan, W. Environmental biogeochemical characteristics of rare earth elements in soil and soilgrown plants of the Hetai goldfield, Guangdong Province, China. Environ. Earth Sci. 2011, 63 (3), 501-511.

(15) Pang, X.; Li, D. C.; Peng, A. Application of rare-earth elements in the agriculture of China and its environmental behavior in soil. Environ. Sci. Pollut. Res. 2002, 9 (2), 143-148.

(16) Hirano, S.; Suzuki, K. T. Exposure, metabolism and toxicity of rare earth and related compounds. Environ. Health Perspect. 1996, 104 (Suppl 1), 85-95.

(17) d'Aquino, L.; Morgana, M.; Carboni, M. A.; Staiano, M.; Antisari, M. V.; Re, M.; Lorito, M.; Vinale, F.; Abadi, K. M.; Woo, S. L. 
Effect of some rare earth elements on the growth and lanthanide accumulation in different Trichoderma strains. Soil Biol. Biochem. 2009, 41 (12), 2406-2413.

(18) Vocaturo, G.; Colombo, F.; Zanoni, M.; Rodi, F.; Sabbioni, E.; Pietra, R. Human exposure to heavy metals. Rare earth pneumoconiosis in occupational workers. Chest 1983, 83 (5), 780-783.

(19) Wang, K.; Cheng, Y.; Yang, X.; Li, R. Cell responses to lanthanides and potential pharmacological actions of lanthanides. Met. Ions Biol. Syst. 2003, 40, 707-751.

(20) Ahren, M.; Selegard, L.; Klasson, A.; Soderlind, F.; Abrikossova, N.; Skoglund, C.; Bengtsson, T.; Engstrom, M.; Kall, P. O.; Uvdal, K. Synthesis and Characterization of PEGylated $\mathrm{Gd}_{2} \mathrm{O}_{3}$ Nanoparticles for MRI Contrast Enhancement. Langmuir 2010, 26 (8), 5753-5762.

(21) Hu, C. G.; Liu, H.; Dong, W. T.; Zhang, Y. Y.; Bao, G.; Lao, C. S.; Wang, Z. L. $\mathrm{La}(\mathrm{OH})_{3}$ and $\mathrm{La}_{2} \mathrm{O}_{3}$ nanobelts - Synthesis and physical properties. Adv. Mater. 2007, 19 (3), 470-474.

(22) Sabbioni, E.; Pietra, R.; Gaglione, P.; Vocaturo, G.; Colombo, F.; Zanoni, M.; Rodi, F. Long-term occupational risk of rare-earth pneumoconiosis. A case report as investigated by neutron activation analysis. Sci. Total Environ. 1982, 26 (1), 19-32.

(23) Zhu, W. F.; Xu, S. Q.; Shao, P. P.; Zhang, H.; Wu, D. S.; Yang, W. J.; Feng, J.; Feng, L. Investigation on liver function among population in high background of rare earth area in south China. Biol. Trace Elem. Res. 2005, 104 (1), 1-8.

(24) Laurent, S.; Elst, L. V.; Muller, R. N. Comparative study of the physicochemical properties of six clinical low molecular weight gadolinium contrast agents. Contrast Media Mol. Imaging 2006, 1 (3), 128-137.

(25) Bouzigues, C.; Gacoin, T.; Alexandrou, A. Biological Applications of Rare-Earth Based Nanoparticles. ACS Nano 2011, 5 (11), 8488-8505.

(26) Gnach, A.; Lipinski, T.; Bednarkiewicz, A.; Rybka, J.; Capobianco, J. A. Upconverting nanoparticles: assessing the toxicity. Chem. Soc. Rev. 2015, 44 (6), 1561-1584.

(27) Geraldes, C. F.; Laurent, S. Classification and basic properties of contrast agents for magnetic resonance imaging. Contrast Media Mol. Imaging 2009, 4 (1), 1-23.

(28) Hu, Z. J.; Ahren, M.; Selegard, L.; Skoglund, C.; Soderlind, F.; Engstrom, M.; Zhang, X. J.; Uvdal, K. Highly Water-Dispersible Surface-Modified Gd2O3 Nanoparticles for Potential Dual-Modal Bioimaging. Chem. - Eur. J. 2013, 19 (38), 12658-12667.

(29) Pagano, G.; Guida, M.; Tommasi, F.; Oral, R. Health effects and toxicity mechanisms of rare earth elements-Knowledge gaps and research prospects. Ecotoxicol. Environ. Saf. 2015, 115, 40-48.

(30) Marckmann, P.; Skov, L.; Rossen, K.; Dupont, A.; Damholt, M. B.; Heaf, J. G.; Thomsen, H. S. Nephrogenic systemic fibrosis: Suspected causative role of gadodiamide used for contrast-enhanced magnetic resonance imaging. J. Am. Soc. Nephrol. 2006, 17 (9), 23592362.

(31) Marciniak, M.; Baltrukiewicz, Z.; Chas, J. The effect of toxic doses of lanthanum and cerium on the placental barrier and the blood/ organ barrier in mice after intravenous injection of these elements. Acta Physiol. Polym. 1988, 39 (4), 294-299.

(32) Nel, A.; Xia, T.; Madler, L.; Li, N. Toxic potential of materials at the nanolevel. Science 2006, 311 (5761), 622-627.

(33) Ma, J.; Li, R.; Qu, G.; Liu, H.; Yan, B.; Xia, T.; Liu, Y.; Liu, S. Carbon nanotubes stimulate synovial inflammation by inducing systemic pro-inflammatory cytokines. Nanoscale 2016, 8 (42), 18070-18086.

(34) Weissleder, R.; Nahrendorf, M.; Pittet, M. J. Imaging macrophages with nanoparticles. Nat. Mater. 2014, 13 (2), 125-138.

(35) Wen, C. P.; Luo, S. Asbestos-related diseases from environmental exposure to crocidolite in Da-yao, China. II. An update study on mesothelloma and lung cancer mortality from a residentially exposed cohort and from local surveys and statistics. Lung Cancer 2006, 54 (Suppl 1), S11-S11.

(36) Li, N.; Xia, T.; Nel, A. E. The role of oxidative stress in ambient particulate matter-induced lung diseases and its implications in the toxicity of engineered nanoparticles. Free Radical Biol. Med. 2008, 44 (9), 1689-1699.

(37) Schmidt-Lauber, C.; Bossaller, L.; Abujudeh, H. H.; Vladimer, G. I.; Christ, A.; Fitzgerald, K. A.; Latz, E.; Gravallese, E. M.; MarshakRothstein, A.; Kay, J. Gadolinium-based compounds induce NLRP3dependent IL-1beta production and peritoneal inflammation. Ann. Rheum. Dis. 2015, 74 (11), 2062-2069.

(38) Li, R. B.; Ji, Z. X.; Chang, C. H.; Dunphy, D. R.; Cai, X. M.; Meng, H.; Zhang, H. Y.; Sun, B. B.; Wang, X.; Dong, J. Y.; Lin, S. J.; Wang, M. Y.; Liao, Y. P.; Brinker, C. J.; Nel, A.; Xia, T. Surface Interactions with Compartmentalized Cellular Phosphates Explain Rare Earth Oxide Nanoparticle Hazard and Provide Opportunities for Safer Design. ACS Nano 2014, 8 (2), 1771-1783.

(39) Qu, G. B.; Wang, X. Y.; Wang, Z.; Liu, S. J.; Jiang, G. B. Cytotoxicity of quantum dots and graphene oxide to erythroid cells and macrophages. Nanoscale Res. Lett. 2013, 8 (1), 198-206.

(40) Qu, G. B.; Liu, S. J.; Zhang, S. P.; Wang, L.; Wang, X. Y.; Sun, B. B.; Yin, N. Y.; Gao, X.; Xia, T.; Chen, J. J.; Jiang, G. B. Graphene Oxide Induces Toll-like Receptor 4 (TLR4)-Dependent Necrosis in Macrophages. ACS Nano 2013, 7 (7), 5732-5745.

(41) Xia, T.; Kovochich, M.; Liong, M.; Zink, J. I.; Nel, A. E. Cationic polystyrene nanosphere toxicity depends on cell-specific endocytic and mitochondrial injury pathways. ACS Nano 2008, 2 (1), 85-96.

(42) Xia, T.; Kovochich, M.; Liong, M.; Madler, L.; Gilbert, B.; Shi, H. B.; Yeh, J. I.; Zink, J. I.; Nel, A. E. Comparison of the Mechanism of Toxicity of Zinc Oxide and Cerium Oxide Nanoparticles Based on Dissolution and Oxidative Stress Properties. ACS Nano 2008, 2 (10), 2121-2134.

(43) Xia, T. A.; Zhao, Y.; Sager, T.; George, S.; Pokhrel, S.; Li, N.; Schoenfeld, D.; Meng, H. A.; Lin, S. J.; Wang, X.; Wang, M. Y.; Ji, Z. X.; Zink, J. I.; Madler, L.; Castranova, V.; Lin, S.; Nel, A. E. Decreased Dissolution of $\mathrm{ZnO}$ by Iron Doping Yields Nanoparticles with Reduced Toxicity in the Rodent Lung and Zebrafish Embryos. ACS Nano 2011, 5 (2), 1223-1235.

(44) Li, R. B.; Ji, Z. X.; Qin, H. Q.; Kang, X. D.; Sun, B. B.; Wang, M. Y.; Chang, C. H.; Wang, X.; Zhang, H. Y.; Zou, H. F.; Nel, A. E.; Xia, $\mathrm{T}$. Interference in Autophagosome Fusion by Rare Earth Nanoparticles Disrupts Autophagic Flux and Regulation of an Interleukin-1 beta Producing Inflammasome. ACS Nano 2014, 8 (10), 1028010292.

(45) Zhang, H. Y.; Ji, Z. X.; Xia, T.; Meng, H.; Low-Kam, C.; Liu, R.; Pokhrel, S.; Lin, S. J.; Wang, X.; Liao, Y. P.; Wang, M. Y.; Li, L. J.; Rallo, R.; Damoiseaux, R.; Telesca, D.; Madler, L.; Cohen, Y.; Zink, J. I.; Nel, A. E. Use of Metal Oxide Nanoparticle Band Gap To Develop a Predictive Paradigm for Oxidative Stress and Acute Pulmonary Inflammation. ACS Nano 2012, 6 (5), 4349-4368.

(46) George, S.; Xia, T.; Rallo, R.; Zhao, Y.; Ji, Z.; Lin, S.; Wang, X.; Zhang, H.; France, B.; Schoenfeld, D.; et al. Use of a High Throughput Screening Approach Coupled With In Vivo Zebrafish Embryo Screening to Develop Hazard Ranking for Engineered Nanomaterials. ACS Nano 2011, 5 (3), 1805-1817.

(47) Cai, X.; Lee, A.; Ji, Z.; Huang, C.; Chang, C. H.; Wang, X.; Liao, Y. P.; Xia, T.; Li, R. Reduction of pulmonary toxicity of metal oxide nanoparticles by phosphonate-based surface passivation. Part. Fibre Toxicol. 2017, 14 (1), 13-26.

(48) Li, R.; Wang, X.; Ji, Z.; Sun, B.; Zhang, H.; Chang, C. H.; Lin, S.; Meng, H.; Liao, Y. P.; Wang, M.; Li, Z.; Hwang, A. A.; Song, T. B.; Xu, R.; Yang, Y.; Zink, J. I.; Nel, A. E.; Xia, T. Surface charge and cellular processing of covalently functionalized multiwall carbon nanotubes determine pulmonary toxicity. ACS Nano 2013, 7 (3), 2352-2368.

(49) Lee, J. H.; Jung, H. W.; Kang, I. K.; Lee, H. B. Cell behaviour on polymer surfaces with different functional groups. Biomaterials 1994, 15 (9), 705-711.

(50) Qu, G. B.; Zhang, C. W.; Yuan, L.; He, J. Y.; Wang, Z.; Wang, L. X.; Liu, S. J.; Jiang, G. B. Quantum dots impair macrophagic morphology and the ability of phagocytosis by inhibiting the Rhoassociated kinase signaling. Nanoscale 2012, 4 (7), 2239-2244.

(51) Wang, Z.; Liu, S.; Ma, J.; Qu, G.; Wang, X.; Yu, S.; He, J.; Liu, J.; Xia, T.; Jiang, G. B. Silver nanoparticles induced RNA polymerase- 
silver binding and RNA transcription inhibition in erythroid progenitor cells. ACS Nano 2013, 7 (5), 4171-4186.

(52) Sato, S.; Takahashi, R.; Sodesawa, T.; Igarashi, A.; Inoue, H. Catalytic reaction of 1,3-butanediol over rare earth oxides. Appl. Catal., A 2007, 328 (2), 109-116.

(53) Mohamed, M. M.; Sloane, B. F. Cysteine cathepsins: multifunctional enzymes in cancer. Nat. Rev. Cancer 2006, 6 (10), 764-775.

(54) Turk, B.; Stoka, V.; Rozman-Pungercar, J.; Cirman, T.; DrogaMazovec, G.; Oreic, K.; Turk, V. Apoptotic pathways: Involvement of lysosomal proteases. Biol. Chem. 2002, 383 (7-8), 1035-1044.

(55) Droga-Mazovec, G.; Bojic, L.; Petelin, A.; Ivanova, S.; Romih, R.; Repnik, U.; Salvesen, G. S.; Stoka, V.; Turk, V.; Turk, B. Cysteine cathepsins trigger caspase-dependent cell death through cleavage of Bid and antiapoptotic Bcl-2 homologues. J. Biol. Chem. 2008, 283 (27), 19140-19150.

(56) Repnik, U.; Hafner Cesen, M.; Turk, B. Lysosomal membrane permeabilization in cell death: concepts and challenges. Mitochondrion 2014, 19 (Pt A), 49-57.

(57) Boya, P.; Kroemer, G. Lysosomal membrane permeabilization in cell death. Oncogene 2008, 27 (50), 6434-6451.

(58) Mizushima, N.; Levine, B.; Cuervo, A. M.; Klionsky, D. J. Autophagy fights disease through cellular self-digestion. Nature 2008, 451 (7182), 1069-1075.

(59) Nakai, A.; Yamaguchi, O.; Takeda, T.; Higuchi, Y.; Hikoso, S.; Taniike, M.; Omiya, S.; Mizote, I.; Matsumura, Y.; Asahi, M.; Nishida, K.; Hori, M.; Mizushima, N.; Otsu, K. The role of autophagy in cardiomyocytes in the basal state and in response to hemodynamic stress. Nat. Med. 2007, 13 (5), 619-624.

(60) Kaur, J.; Debnath, J. Autophagy at the crossroads of catabolism and anabolism. Nat. Rev. Mol. Cell Biol. 2015, 16 (8), 461-472.

(61) Mizushima, N.; Yoshimori, T. How to interpret LC3 immunoblotting. Autophagy 2007, 3 (6), 542-545.

(62) Bagur, R.; Hajnoczky, G. Intracellular $\mathrm{Ca}^{2+}$ Sensing: Its Role in Calcium Homeostasis and Signaling. Mol. Cell 2017, 66 (6), 780-788.

(63) Halestrap, A. P.; McStay, G. P.; Clarke, S. J. The permeability transition pore complex: another view. Biochimie 2002, $84(2-3)$, $153-166$.

(64) Kim, J. S.; He, L. H.; Lemasters, J. J. Mitochondrial permeability transition: a common pathway to necrosis and apoptosis. Biochem. Biophys. Res. Commun. 2003, 304 (3), 463-470.

(65) Kroemer, G.; Galluzzi, L.; Brenner, C. Mitochondrial membrane permeabilization in cell death. Physiol. Rev. 2007, 87 (1), 99-163.

(66) Cirman, T.; Oresic, K.; Mazovec, G. D.; Turk, V.; Reed, J. C.; Myers, R. M.; Salvesen, G. S.; Turk, B. Selective disruption of lysosomes in HeLa cells triggers apoptosis mediated by cleavage of bid by multiple papain-like lysosomal cathepsins. J. Biol. Chem. 2004, 279 (5), 3578-3587. 